\title{
EFFEK SAMPING PENGGUNAAN PONSEL
}

\author{
Enny \\ Pranata Laboratorium Pendidikan Program Studi Diploma III Teknik Elektro \\ Program Studi Diploma III Teknik Elektro \\ Fakultas Teknik Universitas Diponegoro
}

\begin{abstract}
Enny, in this paper explain that many mobile phone users around the us, but only a portion of the concerned about the dangers of cell phones. This paper was compiled to determine the impact and solutions of cell phone radiation. Mobile phones emit electromagnetic waves which will affect the surrounding environment. Based on existing information, cell phone radiation is thought to cause cancer. Waves emitted from mobile phones over the air is causing electromagnetic radiation. Potential disrubtion of health consequences of radiation electromagnetic field has become an issue which examined till now, so found a variety of health disorders as a result of mobile phone users that includes the impact of mild and severe impact. Experts have discovered some efforts to minimize the effects of cell phone radiation on health of mobile phone users. Every user should know the dangers of mobile phone users. Radiation caused cell phone not only arise when used, but when putting a cell phone in your Pocket can also be exposed to any radiation. Therefore, mobile users need to know how to use a cell phone. Users should pay attention to the level of radiation caused by cell phones, so that the influence of electromagnetic radiation on health can be scaled down for mobile users.
\end{abstract}

Keywords: side effects of cell phone use

\section{LATAR BELAKANG}

Di sekeliling kita banyak telepon seluler (ponsel), mulai dari anak kecil hingga orang tua menggunakan ponsel. Bahkan, tidak sedikit orang yang memilki ponsel lebih dari satu buah. Semua orang senang dan tidak ada yang risau tentang bahaya yang timbul dari alat tersebut. Namun, setelah orang mengetahui bahwa ponsel dapat memancarkan gelombang elektromagnetik, berbagai negara maju melakukan riset di bawah koordinasi World Health Organization (WHO). Sejumlah pusat penelitian dan perguruan tinggi juga melakukan riset dengan hasil yang masih kontroversial.

Berbagai opini yang timbul membuat masyarakat menjadi bingung. Di satu sisi ponsel dibutuhkan sebagai alat komunikasi yang penting. Di sisi lainnya masyarakat menjadi ragu untuk menggunakan ponsel. Oleh karena itu, makalah ini disusun karena masyarakat perlu mengetahui hal ini sejak awal. Diperlukannya pengetahuan yang jelas dan informasi yang pasti mengenai hal ini.

\section{TEORI DASAR}

\section{Pengertian GelombangElektromagnetik} Gelombang elektromagnetik yang dirumuskan oleh Maxwell ternyata terbentang dalam rentang frekuensi yang luas. Sebagai sebuah gejala gelombang, gelombang elektromagnetik dapat diidentifikasi berdasarkan frekuensi dan panjang gelombangnya. Cahaya merupakan gelombang elektromagnetik sebagaimana gelombang radio atau sinar-X. Masing-masing memiliki penggunaan yang berbeda meskipun mereka secara fisika menggambarkan gejala yang serupa, yaitu gejala gelombang, lebih khusus lagi gelombang elektromagnetik. Mereka dibedakan berdasarkan frekuensi dan panjang gelombangnya.

\section{Spektrum Gelombang Elektromagnetik}

Susunan semua bentuk gelombang elektromagnetik berdasarkan panjang gelombang dan frekuensinya disebut spektrum elektromagnetik. Gambar spektrum elektromagnetik disusun berdasarkan panjang gelombang (diukur dalam satuan $m$ ) yaitu mencakup kisaran :

- 1. Energi yang sangat rendah, dengan panjang gelombang tinggi dan frekuensi rendah, seperti gelombang radio

- 2. Energi yang sangat tinggi, dengan panjang gelombang rendah dan frekuensi tinggi seperti radiasi X-ray dan Gamma Ray.

Spektrum gelombang elektromagnetik terdiri atas tujuh macam gelombang yang dibedakan berdasarkan frekuensi serta panjang gelombang tetapi cepat rambat di ruang hampa adalah sama, yaitu $\mathrm{c}=3 \times 10^{8} \mathrm{~m} / \mathrm{s}$. Seperti yang sudah dibahas dalam teori Maxwell tentang gelombang elektromagnetik. Frekuensi gelombang terkecil adalah gelombang cahaya serta panjang gelombang terbesar sedangkan frekuensi terbesar adalah sinar gamma serta panjang gelombang terpendek. 




Spektrum gelombang elektromagnetik terdiri dari urutan:

- gelombang radio dan televisi

- $\quad$ gelombang mikr

- infra merah

- cahaya tampak

- ultraviolet

- $\quad$ siar $\mathrm{x}$

- $\quad$ sinar gamma

Urutan dari atas ke bawah adalah frekuensi makin besar serta panjang gelombang makin pendek karena frekuensi dan panjang gelombang berbanding terbalik. Contoh spektrum elektromagnetik adalah :

- Gelombang Radio

Gelombang radio dikelompokkan menurut panjang gelombang atau frekuensinya. Jika panjang gelombang tinggi, maka pasti frekuensinya rendah atau sebaliknya. Frekuensi gelombang radio mulai dari $30 \mathrm{kHz}$ ke atas dan dikelompokkan berdasarkan lebar frekuensinya. Gelombang radio dihasilkan oleh muatan-muatan listrik yang dipercepat melalui kawat-kawat penghantar. Muatan-muatan ini dibangkitkan oleh rangkaian elektronika yang disebut osilator. Gelombang radio ini dipancarkan dari antena dan diterima oleh antena pula. Kamu tidak dapat mendengar radio secara langsung, tetapi penerima radio akan mengubah terlebih dahulu energi gelombang menjadi energi bunyi.

- Gelombang mikro

Gelombang mikro (mikrowaves) adalah gelombang radio dengan frekuensi paling tinggi yaitu diatas $3 \mathrm{GHz}$. Jika gelombang mikro diserap oleh sebuah benda, maka akan muncul efek pemanasan pada benda itu. Jika makanan menyerap radiasi gelombang mikro, maka makanan menjadi panas dalam selang waktu yang sangat singkat. Proses inilah yang dimanfaatkan dalam microwave oven untuk memasak makanan dengan cepat dan ekonomis.

Gelombang mikro juga dimanfaatkan pada pesawat RADAR (Radio Detection and Ranging) RADAR berarti mencari dan menentukan jejak sebuah benda dengan menggunakan gelombang mikro. Pesawat radar memanfaatkan sifat pemantulan gelombang mikro. Karena cepat rambat glombang elektromagnetik c $=3 \times 108 \mathrm{~m} / \mathrm{s}$, maka dengan mengamati selang waktu antara pemancaran dengan penerimaan.

3.Sinar

Inframerah

Sinar inframerah meliputi daerah frekuensi $1011 \mathrm{~Hz}$ sampai $1014 \mathrm{~Hz}$ atau daerah panjang gelombang 10-4 cm sampai $10-1 \mathrm{~cm}$. jika kamu memeriksa spektrum yang dihasilkan oleh sebuah lampu pijar dengan detektor yang dihubungkan pada miliampermeter, maka jarum ampermeter sedikit diatas ujung spektrum merah. Sinar yang tidak dilihat tetapi dapat dideteksi di atas spektrum merah itu disebut radiasi inframerah. Sinar infamerah dihasilkan oleh elektron dalam molekul-molekul yang bergetar karena benda diipanaskan. Jadi setiap benda panas pasti memancarkan sinar inframerah. Jumlah sinar inframerah yang dipancarkan bergantung pada suhu dan warna benda.

- Cahaya tampak

Cahaya tampak sebagai radiasi elektromagnetik yang paling dikenal oleh kita dapat didefinisikan sebagai bagian dari spektrum gelombang elektromagnetik yang dapat dideteksi oleh mata manusia. Panjang gelombang tampak nervariasi tergantung warnanya mulai dari panjang gelombang kirakira 4 x 10-7 m untuk cahaya violet (ungu) sampai 7x 10-7 m untuk cahaya merah. Kegunaan cahaya salah satunya adalah penggunaan laser dalam serat optik pada bidang telekomunikasi dan kedokteran

- .Sinar ultraviolet

Sinar ultraviolet mempunyai frekuensi dalam daerah $1015 \mathrm{~Hz}$ sampai $1016 \mathrm{~Hz}$ atau dalam daerah panjang gelombagn 10-8 m 10-7 m. gelombang ini dihasilkan oleh atom dan molekul dalam nyala listrik. Matahari adalah sumber utama yang memancarkan sinar ultraviolet dipermukaan bumi,lapisan ozon yang ada dalam lapisan atas atmosferlah yang berfungsi menyerap sinar ultraviolet dan meneruskan sinar ultraviolet yang tidak membahayakan kehidupan makluk hidup di bumi.

- $\quad$ Sinar X

Sinar X mempunyai frekuensi antara $10 \mathrm{~Hz}$ sampai $10 \mathrm{~Hz}$. panjang gelombangnya sangat pendek yaitu $10 \mathrm{~cm}$ sampai $10 \mathrm{~cm}$. meskipun seperti itu tapi sinar $\mathrm{X}$ mempunyai daya tembus kuat, dapat menembus buku tebal, kayu tebal beberapa sentimeter dan pelat aluminium setebal $1 \mathrm{~cm}$. 


\section{- Sinar Gamma}

Sinar gamma mempunyai frekuensi antara 10 $\mathrm{Hz}$ sampai $10 \mathrm{~Hz}$ atau panjang gelombang antara $10 \mathrm{~cm}$ sampai $10 \mathrm{~cm}$. Daya tembus paling besar, yang menyebabkan efek yang serius jika diserap oleh jaringan tubuh.

Ponsel termasuk dalam Gelombang Radio. Gelombang radio merupakan gelombang yang memiliki frekuensi paling kecil atau panjang gelombang paling panjang. Gelombang radio berada dalam rentang frekuensi yang luas meliputi beberapa $\mathrm{Hz}$ sampai gigahertz $(\mathrm{GHz}$ atau orde pangkat 9). Gelombang ini dihasilkan oleh alat-alat elektronik berupa rangkaian osilator (variasi dan gabungan dari komponen Resistor (R), induktor (L), dan kapasitor (C)). Oleh karena itu, gelombang radio banyak digunakan dalam sistem telekomunikasi. Siaran TV, radio, dan jaringan telepon seluler menggunakan gelombang dalam rentang gelombang radio ini. Suatu sistem telekomunikasi yang menggunakan gelombang radio sebagai pembawa sinyal informasinya pada dasarnya terdiri dari antena pemancar dan antena penerima. Sebelum dirambatkan sebagai gelombang radio, sinyal informasi dalam berbagai bentuknya (suara pada sistem radio, suara dan data pada sistem seluler, atau suara dan gambar pada sistem TV) terlebih dahulu dimodulasi. Modulasi di sini secara sederhana dinyatakan sebagai penggabungan antara getaran listrik informasi (misalnya suara pada sistem radio) dengan gelombang pembawa frekuensi radio tersebut.

Penggabungan ini menghasilkan gelombang radio termodulasi. Gelombang inilah yang dirambatkan melalui ruang dari pemancar menuju penerima. Oleh karena itu, kita mengenal adanya istilah AM dan FM. Amplitudo modulation (AM) atau modulasi amplitudo menggabungkan getaran listrik dan getaran pembawa berupa perubahan amplitudonya. Adapun frequency modulation (FM) atau modulasi frekuensi menggabungkan getaran listrik dan getaran pembawa dalam bentuk perubahan frekuensinya.

\section{Pengertian Radiasi Elektromagnetik}

Pada ponsel terdapat transmitter yang mengubah suara menjadi gelombang sinusoidal kontinu yang kemudian dipancarkan keluar melalui antena dan gelombang ini berfluktuasi melalui udara. Gelombang radio inilah yang menimbulkan radiasi elektromagnetik.



Gambar 2. Energi Radiasi dari Ponsel

\section{Penelitian Dampak Radiasi Elektromagnetik}

Sebuah studi yang dilakukan oleh Draper (2005) dan koleganya dari Chilhood Cancer Research Group di Oxford University dan John Swanson, penasihat sains di National Grid Transco, menemukan bahwa anak-anak yang tinggal kurang dari 200 meter dari tiang tegangan tinggi, sekitar 70 persen diantaranya terkena leukemia dan yang hidup antara 200-600 meter sekitar 20 persen saja.Pada tahun 1979, Kouwenhoven dan kawankawan dari John Hopkins Hospital melakukan penelitian pada 11 orang tenaga kerja yang bekerja selama 3,5 tahun pada sistem transmisi $345 \mathrm{kV}$. Dilaporkan bahwa tidak ditemukan gangguan kesehatan serta tidak dijumpai adanya proses keganasan. Namun dari hasil analisis sperma, ditemukan bahwa 2 dari 11 tenaga kerja tersebut mengalami penurunan jumlah sperma. Pemeriksaan lanjutan yang dilakukan terhadap 10 tenaga kerja yang masih bekerja sampai 9 tahun kemudian, ternyata tidak ditemukan kelainan bermakna.

Bahkan, sebuah laporan hasil penelitian dari Swedia (European Journal of Cancer Prevention, 2002) menyebutkan bahwa pengguna handphone lebih rentan terkena kanker otak bila dibandingkan dengan yang tidak pernah menggunakan sama sekali. Semakin lama menggunakan, semakin besar resiko terkena kanker otak.Dan masih banyak lagi penelitian, baik dalam dan luar negeri, yang mengamati dampak radiasi elektromagnetik ini.

Namun, secara keseluruhan, belum ada kesepakatan bahwa radiasi elektromagnetik berintensitas rendah sebagaimana dihasilkan oleh peralatan elektronik, jaringan transmisi, maupun peralatan komunikasi, dapat menyebabkan kanker.Menurut Prof.Dr.dr.Anies,M.Kes,PKK, dalam bukunya "Cepat Tua Akibat Radiasi", bahwa karena belum ada bukti yang menyakinkan bahwa pajanan radiasi elektromagnetik menginduksi perubahan genetik maka tampaknya pajanan tidak memberikan efek baik inisiasi maupun konversi.

Tidak adanya efek pada struktur kromosom menunjukkan bahwa pajanan radiasi elektromagnetik lebih berperan sebagai promotor daripada sebagai inisiator, dengan meningkatkan laju proliferasi sel terubah secara genetik daripada menyebabkan kerusakan awal pada DNA atau kromatin.Reiter (1997) melaporkan, bahwa pengaruh pemajanan medan elektromagnetik dapat mempengaruhi metabolisme serotonin dan melatonin pada kelenjar pineal yang bertugas menekan timbulnya "tumorogenesis" pada dada.

Dengan rendahnya produksi melatonin maka hal ini sangat berpotensi menimbulkan kanker dada. Pengaruh pada penekanan hormon melatonin ini juga dibuktikan oleh Kato dan Shigemitsu dan penelitian Kasper yang dikutip oleh Brinkmann, menghubungkan penurunan hormon melatonin serum dengan gangguan depresi. 


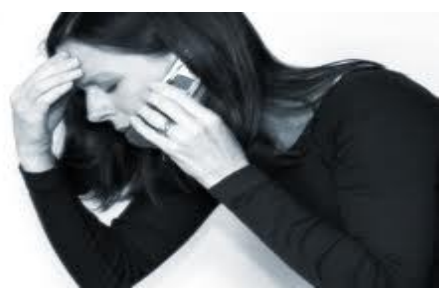

Gambar 3. Dampak Radiasi Ponsel pada Kesehatan

\section{Efek Samping Penggunaan Ponsel}

Sebagian orang mengalami apa yang disebut sebagai electrical hypersensitivity, yang merupakan gejala hipersensitif akibat pengaruh radiasi medan elektromagnetik, ditandai dengan sekumpulan gejala neurologis dan kepekaan (sensitivitas) terhadap medan elektromagnetik. Dalam penelitian Anies (2004), sebagian besar penduduk yang mengalami electrical sensitivity, berupa kombinasi gangguan yang terdiri atas tiga gejala, yang dikenal sebagai "Trias Anies", yaitu: sakit kepala (headache), pening (dizzines), dan keletihan menahun (chronic fatigue syndrome).Kalau terlalu lama ditempelkan pada telinga, berikut antenanya yang menyentuh kepala, handphone bisa membuat orang mengalami nyeri kepala dan pening, karena pembuluh darah di lehernya menyempit sampai meningkatkan tekanan darah. Dalam penelitian di Jerman, ditemukan bahwa pemaparan selama 35 menit meningkatkan tekanan darah sampai $5-10$ $\mathrm{mmHg}$, kalau handphone terus-menerus dipakai mengobrol dan menempel pada telinga. Bagi penderita tekanan darah tinggi, kenaikan sebesar itu sudah membahayakan.

\section{ANALISA DATA \\ Dampak Ringan}

- Vertigo

Vertigo adalah gejala yang dialami oleh individu yang merasa sekelilingnya berputar. Ada yang menyebutnya sebagai "halusinasi gerakan" atau "ilusi bergerak". Individu yang bersangkutan merasakan adanya sensasi berputar-putar yang disertai dengan rasa mual, muntah, telinga berdenging, sakit kepala, dan kelelahan. Kondisi yang terkadang menimbulkan vertigo diantaranya pengerasan pembuluh darah (arteriosclerosis), gangguan pada pembuluh otak, kafein, nikotin, dan alkohol. Namun, menurut teori terbaru tentang melatonin, melatonin yang rendah dapat menimbulkan gejala ini. Salah satu penghambat produksi hormon melatonin adalah radiasi elektromagnetik, termasuk berasal dari ponsel.

- Keletihan Menahun (Chronic Fatigue Syndrome)

Tanda awal gangguan ini berupa keletihan yang kuat, terjadi secara tiba-tiba dan selalu berulang. Pada umumnya penderita mula-mula menderita bronkhitis, pilik, hepatitis, atau stres emosional. Namun, sebagian orang yang hipersensitif terhadap radiasi elektromagnetik akan mengalaminya. Radiasi medan elektromagnetik akan menimbulkan penurunan produksi hormon melatonin. Secara umum, keluhan pada keletihan menahun dapat berupa rasa lemah pada otot yang menetap atau hilang timbul, rasa sakit pada otot yang menetap atau hilang timbul, rasa lemah atau sakit pada otot dan persendian secara bersamaan yang menetap atau hilang timbul.

\section{Dampak Berat}

- Insomnia

Insomnia adalah persepsi tentang kurangnya kualitas dan kuantitas tidur, dengan akibat yang terkait pada siang hari. Keluhan yang dikemukakan, yaitu sulit memulai tidur, sering terbangun dari tidur, sulit tidur lagi setelah terbangun malam hari, dan cepat bangun di pagi hari. Sesuai definisinya, gejala tersebut berhubungan dengan gangguan di siang hari, misalnya keletihan, konsentrasi maupun memori terganggu, dan sebagainya. Namun, hormon melatonin yang turun, antara lain karena rangsangan sinar yang terang serta radiasi elektromagnetik ponsel, juga dapat menimbulkan gangguan ini. Diagnosis lain tentang penyebab insomnia mencakup gangguan neuropsikiatri seperti depresi, ansietas, demensia, juga penyalahgunaan obat, maupun gangguan irama sirkadian. 'Salah satu penyebab gangguan irama sirkadian yang menyebabkan orang sukar tidur adalah radiasi elektromagnetik'. Itulah yang diucapkan oleh Anies (2009:65). Irama sirkadian yang terganggu menyebabkan terganggunya irama bangun dan tidurnya seseorang. Jika hal tersebut terjadi, maka orang yang bersangkutan akan mengantuk dan tidur siang hari, sedangkan di malam hari ia justru akan terbangun dan sulit untuk tidur.

- Leukimia

Leukemia dapat menyerang pria dan wanita, tetapi angka kejadian leukemia pada umumnya menyerang lebih banyak pria daripada wanita. Faktor keturunan dan lingkungan berperan dalam terjadinya leukemia. Faktor-faktor lingkungan berupa kontak dengan radiasi. Radiasi di sini terutama berupa radiasi pegion, meskipun untuk kondisi tertentu juga berasal dari radiasi nonpegion.Tanda dan gejala leukemia akut adalah infeksi berat disertai timbulnya luka pada selaput lendir, demam, napas cepat, mimisan, dan perdarahan saluran cerna dan sistem saluran kemih. Dapat pula timbul gejala kurang darah seperti pusing, cepat lelah, susah bernapas sewaktu bekerja fisik, dan pucat yang nyata. Sedangkan tanda 
dan gejala leukemia kronik dapat berupa kelelahan, kehilangan berat badan, produksi keringat yang meningkat, tidak tahan panas, cepat kenyang, dan buang air besar tidak teratur.Semua tanda dan gejala pada leukemia, baik akut maupun kronik, dapat merupakan gejala dan tanda khas dari tiap-tiap leukemia ataupun merupakan gejala dan tanda gabungan dari kedua jenis leukemia.

- Kanker Payudara

Kanker payudara merupakan penyakit yang sangat ditakuti oleh perempuan. Penyakit ini tidak dapat disembuhkan dan angka kematiannya cukup tinggi. Penyebab pasti penyakit ini belum diketahui, meskipun banyak dugaan-dugaan yang disimpulkan oleh para peneliti.Ternyata lingkungan berhubungan berat dengan kanker payudara, dalam hal ini sebagai pemicu timbulnya kanker tersebut. Paparan bahan-bahan radioaktif, sinar-Xserta bahan lain yang termasuk radiasi pegion, beresiko menimbulkan kanker payudara. 'Bukan hanya radiasi pegion saja, bahkan radiasi seperti radiasi nonpegion seperti radiasi elektromagnetik yang berasal dari berbagai peralatan elektronik, dalam taraf tertentu berisiko menimbulkan kanker payudara'. Sebagaimana dikemukakan oleh Harmaya (2009) dan Mahendra (2008). 'Keterkaitan radiasi elektromagnetik dengan kanker payudara tidak serta merta terjadi begitu saja, melainkan melalui mekanisme hormonal, khususnya hormon melatonin. Hormon melatonin bersifat menghambat tumorogenesis. Artinya hormon melatonin yang turun, salah satunya adalah akibat radiasi elektromagnetik yang berpotensi menimbulkan kanker payudara'. Itulah pendapat Anies (2009:74).

\section{- Teori Melatonin}

Hormon melatonin adalah hormon yang sebagian besar dibuat oleh kelenjar pineal, sebuah kelenjar sebesar kacang tanah yag terletak di antara kedua sisi otak', Anies (2009:83).Melatonin berfungsi mengatur hormon-hormon lainnya serta memelihara irama sirkadian. Irama sirkadian adalah suatu sistem pemeliharaan waktu 24 jam yang berperan penting dalam menentukan kapan kita tidur dan kapan kita bangun. Kadar melatonin dalam tubuh dapat mempengaruhi sistem kekebalan tubuh, memengaruhi kinerja organorgan reproduksi, juga kesehatan psikologis serta proses penuaan tubuh. Kelenjar pineal dalam memproduksi melatonin, sangat sensitif terhadap cahaya matahari dan suhu lingkungan. Ketika kegelapan datang dalam bentuk malam hari, reseptor melatonin diaktifkan dan kemudian menyebabkan efek-efek kimiawi dan biologis dalam bentuk rasa kantuk serta penurunan suhu tubuh. Aktivitas organ-organ akan berkurang dan bersiap-siap istirahat. Produksi hormon melatonin bertambah pada malam hari, terutama pada suasana hening dan gelap sehingga menyebabkan orang mudah tidur. Namun, produksi hormon ini berkurang oleh adanya rangsangan dari luar, misalnya cahaya serta medan elektromagnetik. Sebagaimana dikemukakan oleh Mahendra (2008) bahwa, 'Cahaya maupun medan elektromagnetik dapat menurunkan produksi hormon melatonin dan berpotensi menimbulkan berbagai keluhan termasuk sakit kepala, pening, dan keletihan'. Penggunaan peralatan elektronik maupun komunikasi pada malam hari yang menimbulkan radiasi elektromagnetik, merupakan salah satu alasan gangguan sukar tidur pada malam hari. Banyak orang kesal karena sukar tidur pada malam hari, tetapi tidak menyadari bahwa sebelumnya telah berkomunikasi menggunakan ponsel dalam jangka waktu lama. Anies (2009:86) menemukan bahwa, 'Timbulnya berbagai keluhan seperti sakit kepala banyak dijumpai pada para pemakai ponsel'. 'Sensasi medan elektromagnetik dapat menimbulkan keluhan sakit kepala dan pening'. Itulah yang dikatakan oleh Harmaya (2009) maupun Mahendra (2008) .

\section{Pembuktian Dari Penggunaan Ponsel}

Sungguh tragis mendapati bahwa handphone (HP) yang setiap hari kita pakai ternyata memiliki radiasi yang cukup mematikan dalam jangka panjang kita tidak berhati-hati menggunakannya. Yang juga mengejutkan adalah radiasi HP ternyata juga bisa dipakai untuk mematangkan sebutir telur seperti microwave. Untuk membuktikannya, dibutuhkan:

- 1 butir telur dan 2 HP. Telur diletakkan di tengah-tengah kedua HP.

- 65 menit percakapan ke 2 HP tersebut.

- Buktikan!!! Telur tersebut telah matang dan siap dimakan. Otak kita jg akan menjadi matang bila terus menerus ditempelkan pada HP. Otak dan telur sama-sama mengandung jumlah air dan protein.

- Mulailah panggilan antara kedua HP selama kurang lebih 65 menit

- 15 menit tidak terjadi apa-apa

- $\quad$ Setelah 25 menit telur mulai hangat, setelah 45 menit, buktikan sendiri!

\section{Solusi Mengurangi Dampak Radiasi Elektromagnetik Ponsel}

Pakar kesehatan menemukan beberapa upaya untuk memperkecil pengaruh radiasi ponsel terhadap kesehatan pengguna ponsel. Upaya tersebut meliputi: 
- Menjauhkan ponsel dari kepala. Kekuatan gelombang elektromagnetik akan berkurang secara drastis dengan bertambahnya jarak,

- Pergunakan headset atau handsfree seefektif mungkin,

- Memanfaatkan layanan pesan singkat (SMS) dibanding telepon,

- Tidak menggunakan ponsel sewaktu sinyal lemah,

- Tunggulah sampai telepon sudah menyambung ke tempat tujuan, sebelum mendekatkan ponsel ke telinga,

- Jangan menyimpan ponsel di saku atau ikat pinggang pada saat ponsel dalam kondisi on,

- Dalam buku manual ponsel selalu dianjurkan untuk mematikan ponsel pada saat berada di dekat pompa bensin maupun tempat-tempat penyimpanan bahan kimia yang mudah meledak. Ponsel dapat mengganggu operasi instalasi teknis dari tempat-tempat tersebut,

- Meminimalisir pemakaian ponsel di ruang tertutup dengan bahan logam atau baja, misalnya di dalam mobil,

- Memilih ponsel dengan level SAR (Spesific Absorption Rate) yang rendah. Level SAR ini biasanya dicantumkan dalam buku manual. ICNIRP (International Commission on NonIonizing Radiation Protection) memberikan batas maksimal sebesar 2,0 W/kg.

\section{KESIMPULAN}

Berdasarkan informasi yang telah didapatkan dari penyusunan makalah, ternyata ponsel mempunyai dampak yang akan mengganggu kesehatan penggunanya. Dari penyakit ringan seperti vertigo hingga penyakit berbahaya seperti kanker pun dapat membahayakan penggunanya. Radiasi ponsel timbul tidak hanya saat digunakan, tetapi saat meletakkan ponsel di saku juga dapat menyebabkan radiasi. Oleh karena itu, sebagai pengguna ponsel kita harus menyadari hal tersebut dan lebih berhati-hati dalam menggunakan ponsel, dengan cara meminimalisir waktu pemakaian ponsel serta memaksimalkan jarak ponsel dengan tubuh kita (dalam kondisi menyala).

\section{DAFTAR PUSTAKA}

1. Anies. 2009. Cepat Tua Akibat Radiasi. Jakarta:Elex Media Komputindo.

2. Mahendra,Oka. (2009). Radiasi Ponsel Bagi Kesehatan. [Online]. Tersedia: http://tutorialgratis.net.

3. http://erisfauzan.netne.net/index.php?option=c om_content\&view=article\&id=4:gelombangelektromagnetik\&catid=1:materibelajar\&Itemid $=5$

4. http://eharmayaku.blogspot.com/2009/08/efek -radiasi-elektromagnetik-dari.html 